\title{
Effect by Contact and Ingestion of Essential Oils of Pennyroyal: Mentha pulegium L.(Lamiaceae) on Juvenile of Calliptamus barbrus (Orthoptera: Calliptaminae)
}

\author{
Moad Rouibah $^{1}$, Rabah Bouredjoul ${ }^{2} \&$ Salaheddine Kouahi ${ }^{3}$ \\ ${ }^{1}$ Department of Environment and agronomic sciences, Universty of Jijel, Algeria \\ Correspondence: Moad Rouibah, 11rue Arid Seddik, Jijel 18000, Algeria. Tel: 213-558-314-082. E-mail: \\ rouibahm@yahoo.com
}

Received: May 1, 2020 Accepted: May 18, 2020 Online Published: May 21, 2020

\begin{abstract}
This work is a study on the action of essential oils (EOs)of Pennyroyal Mentha pulegium against two larvaeL2 and L3 of Calliptamus barbarus (Orthoptera: Acrididae). The EOsare extracted by hydrodistillation protocol based on the use of a Clevenger. It should be noted that the yield of EOs obtained at the flowering stage $(2.2 \%)$ is almost double that obtained at the foliage stage (1.2\%). Gas Chromatography coupled to a mass spectrophometerGC-MS analysis revealed the presence of p-Menth-4 (8) -en-3-one, as the most frequently constituents of Mint, better known as Pulegone.

We performed two ways of treatments: by contact and by alimentation (the duration of treatment is 3 and 6 days respectively).

By contact we have acquired a total mortality $(100 \%)$ using the highest dose $(48 \mu \mathrm{l} / \mathrm{ml})$ with a LD50 of $12.58 \mu \mathrm{l} /$ $\mathrm{ml}$. In the opposite, by ingestion, the mortality rate obtained for the same dose was $80 \%$ while the LD50 was 23.98 $\mu \mathrm{l} / \mathrm{ml}$.

Using the letal doses, the comparative effect of contact and ingestion between the essential oils show that the action by contact is stronger and faster to enter in the insect via the cuticulethan that byingestion. Finally authors concluded that the results were very satisfactory.
\end{abstract}

Keywords: Calliptamus barbarus, Mentapulegium, Essential oil, lethal dose, mortality

\section{Introduction}

Food security is based on the protection of crops from pests, including grasshoppers and locusts. In Algeria, Calliptamus barbarus (Orthoptera: Calliptaminae) is a potentially dangerous species especially during outbreaks, causing enormous damage. It is characterized by a chromatic polymorphism of the hind femora (femore red with three spots or orange with only one spot). It was found for two areas: Littoral region for the form with three femoral spots, and extremely semiarid and dry inhabitants for the form with only one femoral spot (Rouibah et al., 2019).

In agriculture, the protection of crops against pests is achieved essentially through chemical way. This is based on the application of various phytosanitary products of synthesis (Regnault-Rogeret al.,2002). However, natural products are increasingly sought after for agriculture sustainable (Regnault-Roger et al., 2008), and this because of the negative impact of synthetic products on health and the environment. Currently one of the natural forms which aroused the interest of scientists is the use of biobesticide of vegetable origin based on the extraction of aqueous extracts and other natural essences.

In order to control the larvae of C.barbarus, the choice was made on the Pennyroyal: Mentha pulegium(Lamiaceae). Pennyroyal is a plant of the Lamiaceae family, it is sometimes cultivated for these leaves. It is a perennial herb with a strong aromatic odor. The height is 15 to $4 \mathrm{~cm}$, the flowers are pink. According to Benayad (2008) and Bouziane (2012), this plant is native to Europe and Asia Minor. It is found in almost all regions either in the spontaneous or cultivated state, but exists frequently in humid regions (Beloued, 2009).

Several studies were realized on this plant in differents part of the world: Pinoet al. (1996) in Cuba, Marzouket al. (2008) in Tunisia, Chalchatand Maksimović (2000) in Ex Yougoslavia, Rocha et al. (2015) in Portugal, Abdelliet al. (20016) in Algeria and Casigliaet al. (2017) in Sicily (Italy). M. pulegium is known for its therapeutic virtues (Karousouet al., 2007), especially thanks to its essential oils. Pennyroyal also contains tannin and cellulose 
(Beloued, 2009). it's an excellent digestive, stimulates gastric secretions, reduces flatulence and can be used as an insecticide (Iserin, 2001 and Alloum (2007).

The mechanisms by which bioactive substances of Pennyroyal act are little known, despite the studies devoted to them. According to Isman (2000), they are considered to be unique and that biopesticides based essential oils can be tools of choice in health management programs pest resistance to pesticides. Currently, essential oils hold an important place in the control systems, their role in the phytopharmaceutical research in certain countries of the world no longer needs to be demonstrated (Lahlou,2004).

This work is a continuation of that already carried out by Rouibahet al. (2019) on the effect of the aqueous extracts of Harmal Peganumharmal (Zygophyllaceae) having given very good results on the larvae of C.barbarus. So we propose to evaluate the bioinsecticide activity of the essential oils of the leaves of Pennyroyal: Mentha pulegium L (Labiae) against the larva of this pest locust by two methods: the direct contact and their effect by alimentation.

\section{Material and Methods}

\subsection{Material Used}

The plant and animal material (Figure 1,2) used for this experiment, came from the Jijel region (North East of Algeria). This work was carried out at the zoology laboratory of the University of Jijel from april to may 2014. To rear the insects, a breeding cage of dimensions $(30 \times 20 \times 20 \mathrm{~cm})$ was used. Other materials like a manual sprayer, an analytical balance, a magnetic stirrer, an electric mixer, aluminum foil, cotton wool and Wattman paper $\mathrm{n}^{\circ}$ 3 were also essential for carrying out this experiment. As reagents, mainly acetone and methanol have been used for the extraction of bioactive substances. As for the glassware, it is made up of a flask, petri boxes, beakers, test tubes, pipette, funnel, etc.

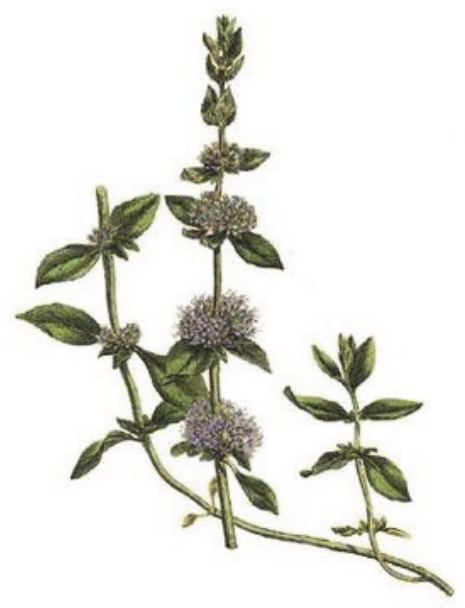

Figure 1. M. pulegium leaves and flowers

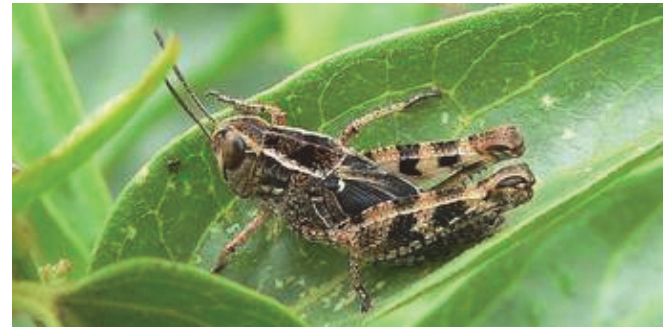

Figure 2. C. barbarus larvae

The bioactive substances tested are the essential oils (EOs) extracted leaves of the Pennyroyal. The method of hydrodistillation has been adopted for the extraction of these essential oils. Once the substances are obtained, the yield is calculated, the chemical composition analyzed. Finally, the acridicidal effectis tested.

\subsection{Extraction of Essential Oils: Hydrodistillation Protocol}

Once collected, the leaves were first rinsed with distilled water and then dried in the shade for8 days. The purpose of the drying operation is especially to promote the inhibition of any enzymatic activity (Wichtl and Anton, 1991). Dried plants are ground using a blender until powders are obtained.

The essential oils of Pennyroyal are obtained by hydrodistillation. It is a method based on the use of a Clevenger, using dried leaves with distilled water. This consists of a balloon heater, a glass balloon with distilled water and dried plants, a capacitor and a collector that receives the extracts from distillation (Figure3).

The experimental hydrodistillation protocol employed here is that proposed by (Pavidaet al., 1976), with some modifications: $50 \mathrm{~g}$ instead of 100 and $700 \mathrm{ml}$ of distilled water instead of 1400. According to (El Haib, 2011) the duration of a hydrodistillation can vary considerably. It can influence not only the yield but also the composition 
of the extract. This operation was carried out for 3hours by boiling a mixture of $100 \mathrm{~g}$ of dried plant in $1400 \mathrm{ml}$ of distilled water. The separation of essential oils is made in the florentine vase by means of the difference in density with distilled water. The oils thus obtained are stored at $4{ }^{\circ} \mathrm{C}$ in hermetically sealed tubes covered with aluminum foil.

\subsection{Calculation of Yield and Analysis of Chemical Composition}

The oil yield is expressed as a percentage relative to the dry matter according to the following formula (Pavidaet al., 1976):

$$
\text { Yield }=\text { Weight of extract (oil) / Weight of dry matter } x 100
$$

The chemical composition of essential oils is analyzed using gas chromatography and an a polar capillary column Coupled to a Mass Spectrometer. A small amount of essential oil is injected into the GC column. The temperature conditions are different. The injection takes place at $250^{\circ} \mathrm{C}$. The oven is carried out successively at $55^{\circ} \mathrm{C}$ for $3 \mathrm{~min}$, $120^{\circ} \mathrm{C}$ for $5 \mathrm{~min}$ and $180^{\circ} \mathrm{C}$ for $11 \mathrm{~min}$. Finally, the interface is performed at $250^{\circ} \mathrm{C}$.

The chromatogram is coupled to a mass spectrum to identify the chemical compositions. On the other hand, the quantitative analysis is carried out using the retention index in the stationary phase. The result is represented in the form of graphs having several peaks. Each peak makes it possible to distinguish a chemical compound. The area of these peaks helps to quantify the percentages of the different constituents of EOs in relation to the total concentration of the constituents.

\subsection{Efficacy Tests}

Firstly, the C. barbarus larvae) were placed incages. The larvae were feed with wheat seedlings supplemented with bran (Benzara et al.,2010). These last were then isolated in batches of 10 individuals in insect boxes. The experimental conditions in the laboratory are the same as those in the field. Essential oils were powdered directly on insects for treatment by contact in captivity or mixed with food for treatment by ingestion. Note that the contact and ingestion method has already been used by Abdelliet al. (2016) against Sitophilus granarius (Coleoptera: Curculionidae).

The following doses were prepared: $6,12,24$ and $48 \mu \mathrm{l}$ of active substance per $\mathrm{ml}$ of diluent (distilled water and acetone). To confirm the biological tests, two controls are used. One negative (distilled water) and the other positive, an insecticide named (ACEPLAN 20). For it, 16 boxes of insects are used, one box per dose.

For contact treatment, the mortality rate were read 1, 2 and 3 days after spraying the product. On the other hand, for treatment by ingestion, the results are read 2, 4 and 6 days after the application of the product, in order to allow the product to act well against insects.

To calculate LD 50 (lethal dose to kill $50 \%$ of population), doses are converted to log doses and cumulative mortality in Probit (Table 3). The equation of the linear regression line is calculated from the data in Table 1.

Table 1. Logarithms of doses and Probit of cumulative mortality for the test of EOs by contact

\begin{tabular}{llll}
\hline Dose $(\mu \mathrm{l} / \mathrm{ml})$ & Log dose & Cumulative mortality (\%) & Probit \\
\hline 6 & 0,778 & 20 & 4,16 \\
12 & 1,079 & 30 & 4,48 \\
24 & 1,380 & 60 & 5,25 \\
48 & 1,681 & 100 & 8,1 \\
\hline
\end{tabular}




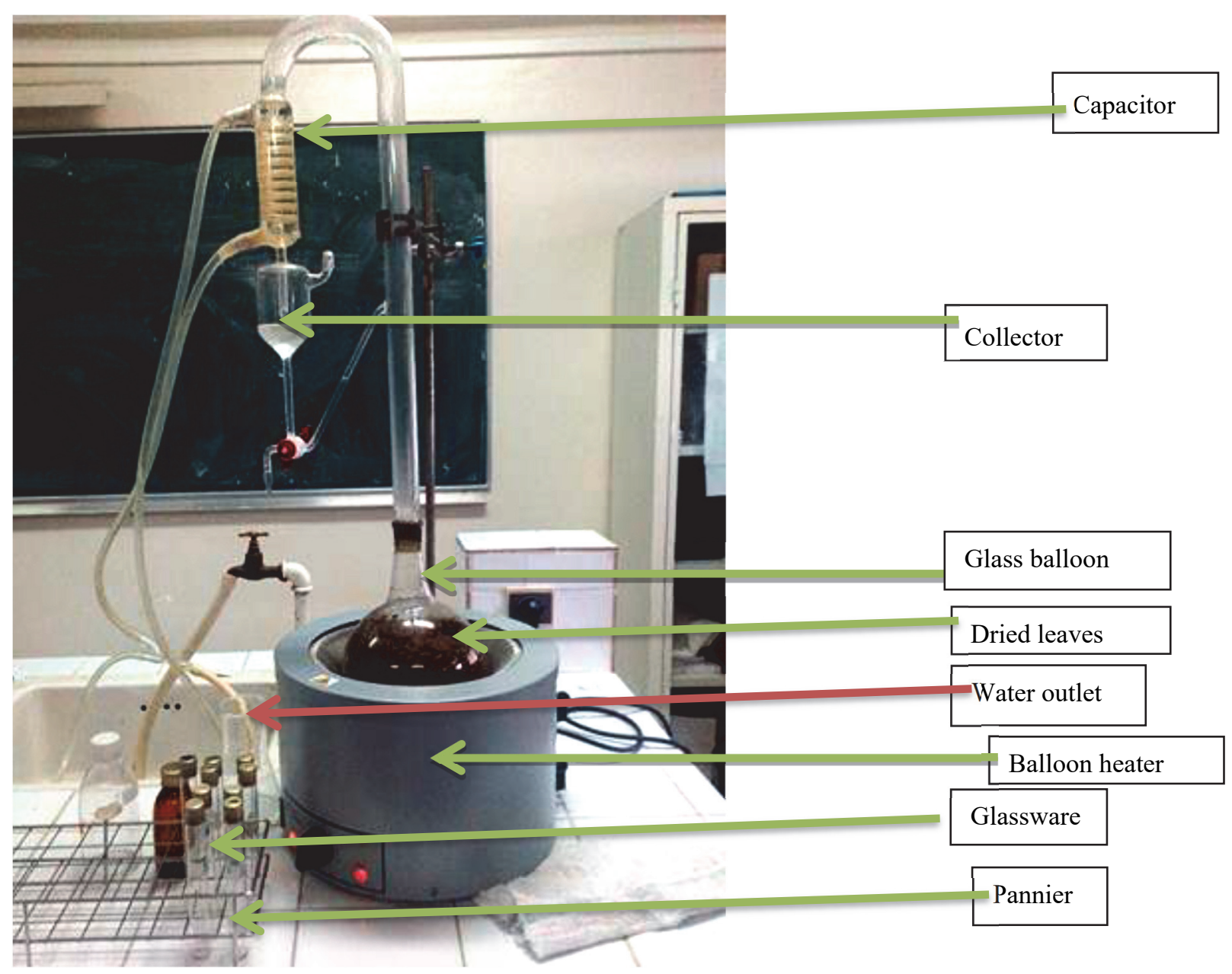

Figure 3. Clevenger hydrodistillation assembly

\section{Results and Discussion}

\subsection{Yield of Essential Oils}

Looking at figure 4, It should be noted that the yield obtained at the flowering stage $(2.2 \%)$ is almost double that obtained at the leafing stage (1.2\%) This confirms the fact that the essential oils content increased at the flowering state of Pennyroyal (Marzouket al., 2008). This result is almost similar to that obtained by Abdelliet al. (2016) in the region of Bouira (Algeria): $1.45 \%$ or that of Stoyanovaet al. (2005) obtained by steam distillation in Bulgaria (1.48\%). However our result is higher than that obtained by Rochaet al. (2015) in Portugal: $0.6 \%$ or Chalchat and Maksimović (2000) who got only 0.2 \%in flowering period in Ex Yoygoslavia.

This can be explained by the climate and the nature of the soil specific to each region and its influence on the growth of the plant and therefore on the composition of essential oils without forgetting the extraction method used by each author. 


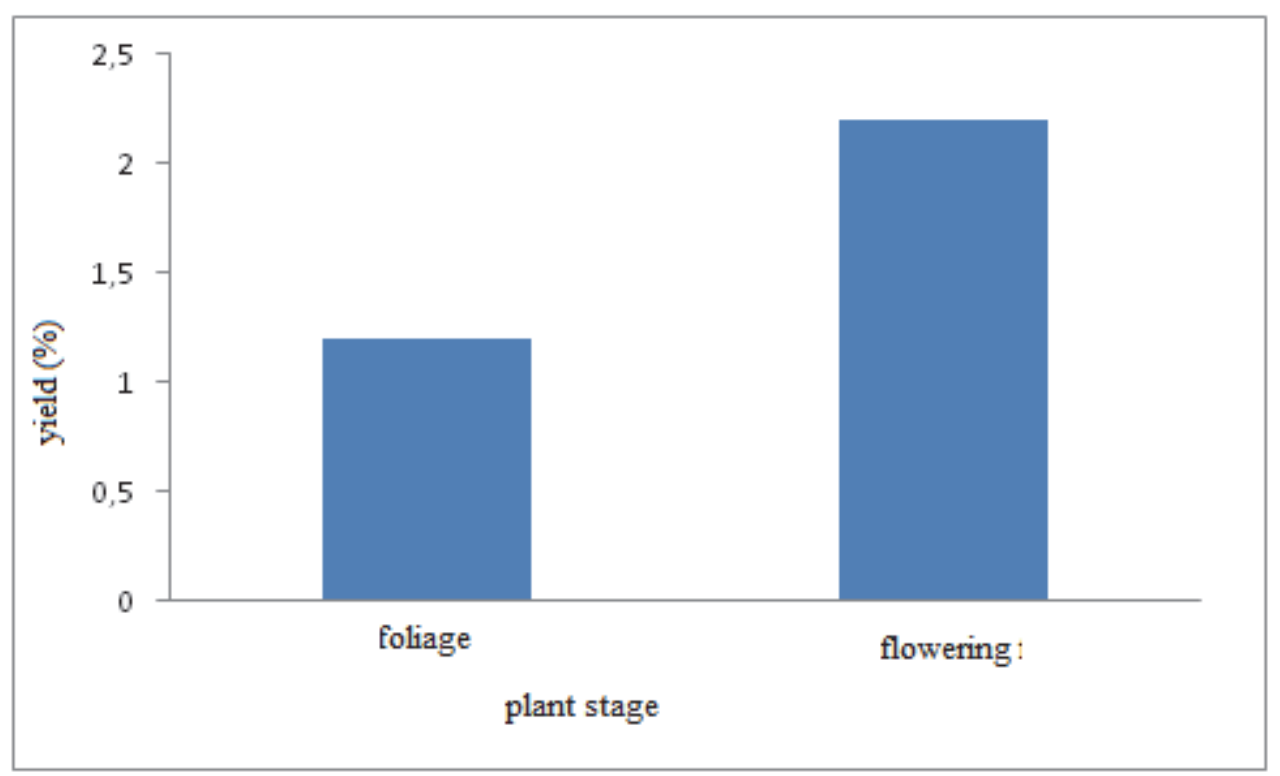

Figure 4. Yield of essential oils of Pennyroyal

\subsection{Determination of Essential Oils Composition}

Chromatography analysis of the constituents of EOs of M.pulegium revealed a spectrum consisting of 31 components, with different concentrations from one component to another (Table2). The most dominant of these is p-Menth-4 (8) -en-3-one, better known as "Pulegone" with a rate of $84.11 \%$. It is defined according to Larousse in 2014, as a monoterpene ketone $\mathrm{C} 10 \mathrm{H} 16 \mathrm{O}$, contained in the essence of Pennyroyal and used in perfumery.

Several studied showed that the quality and quantity of the constituents of Pennyroyal varies according to the sampling regions. For example, In Algeria Abdelliet al. (2016) found 39 compounds of which the overwhelming majority were pulegone (71\%) and neo-menthol (11\%). In Ex You go Slavia Chalchat and Maksimović (2000) have revealed the presence of 22 components whose $31 \%$ are Menthone while the other important were pulegone and neomenthol with the same rate (14\%). According to Rocha et al. (2015), in Portugal pulegone (61\%) and menthone (20\%) were the main EO constituents of this plant. For their part, Marzouket al. (2008) have identified the presence in Tunisia of 34 constituents. The majority of them were menthol $(50 \%)$, but only $4 \%$ for pulegone (Marzouket al. 2008).

Table 2. Chemical composition of essential oils of M. pulegium

\begin{tabular}{llll}
\hline Peak N & Constituents & & Mean percentage \\
\hline 1 & Alpha-pinene & 0.31 & \\
2 & Bicyclohexane & 0.06 & \\
3 & Bicycloheptane & 0.24 & \\
4 & Octanol & $\mathbf{3 . 0 6}$ & \\
5 & Cyclobutane & 0.05 & \\
6 & Octanol-acetate & 0.78 \\
7 & Cyclohexanone-menthan & 0.38 \\
8 & Cyclohexanone & 0.05 \\
9 & Benzofuran & 0.94 \\
10 & Cyclohexanone-trans & $\mathbf{2 . 7 9}$ \\
11 & Cyclohexanol & 0.10 \\
\hline
\end{tabular}




\begin{tabular}{lll}
\hline 13 & Pulegone & $\mathbf{8 4 . 1 1}$ \\
14 & Trymethylhept & 0.02 \\
15 & Octadienal & 0.24 \\
16 & Metoxy-venylphenol & 0.09 \\
17 & Bicyclo-trimethyl & 0.29 \\
18 & Copaene & 0.05 \\
19 & Octadien-acetate & 0.06 \\
20 & Cyclobuta & 0.07 \\
21 & Cyclohexane & 0.04 \\
22 & Caryophyllene & 0.94 \\
23 & Alpha-caryophyllene & 1.23 \\
24 & Cyclodecadiene methyl & 1.30 \\
25 & Benzene & 0.36 \\
26 & CyclodecadieneDimethyl & 0.17 \\
27 & Naphtalene & 0.06 \\
28 & Cycloproptrimethyl & 0.027 \\
29 & Cycloproptetramethyl & 0.26 \\
30 & Cadinol & 0.07 \\
31 & Hetoxyhexamethyl & 0.06 \\
\hline
\end{tabular}

\subsection{Efficacy Tests}

The actions by contact and then by ingestion of the essential oil against juveniles of $C$. barbarusis presented separately.

\subsubsection{Effect by Contact}

The effct of M.pulegium EOs (Figure5) onthe larvae of C. barbarusresulted in a total mortality of $100 \%$ (more than thechemical insecticide) This mortality is obtained from the first day of treatment butwith a very high dose $(48 \mu \mathrm{l} / \mathrm{ml})$.

In the opposite, the death rate was zero at lowest dose $(6 \mu \mathrm{l} / \mathrm{ml})$ during the first day and caused low mortality in the following days (less than $20 \%$ ). Concerning the other doses $(12$ and $24 \mu \mathrm{l} / \mathrm{ml})$, we obtained an average effect on the larvae of $C$. barbarus (between 10 and $50 \%$ ). 


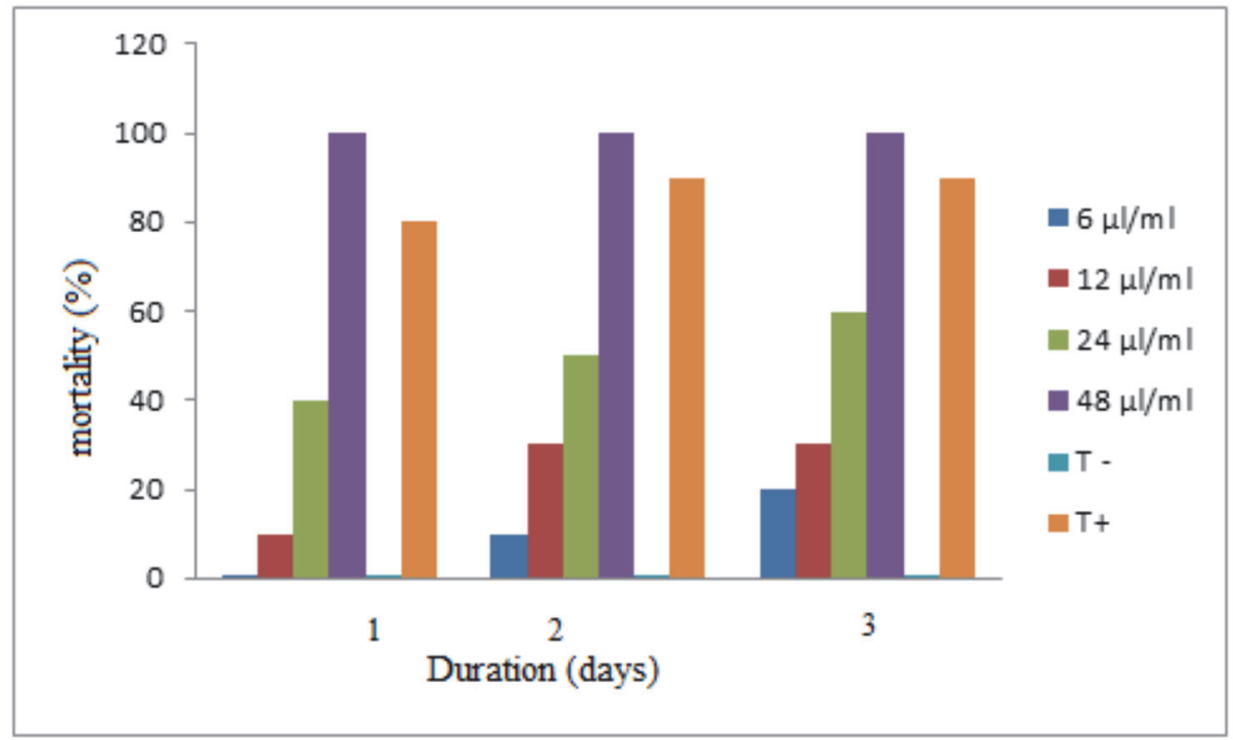

Figure 5. Contact effect of EOs

The linear equation of dose-specific mortality rates obtained after 3 days of treatment is: $\mathrm{y}=1.9275 \mathrm{x}$ +9.1304 (Figure6). The coefficient correlation $\mathrm{r}^{2}$ is equal to 0.9924 . It means that EOs treatment effect by contact of M. pulegium caused $99.24 \%$ of mortality in C.barbarus population.

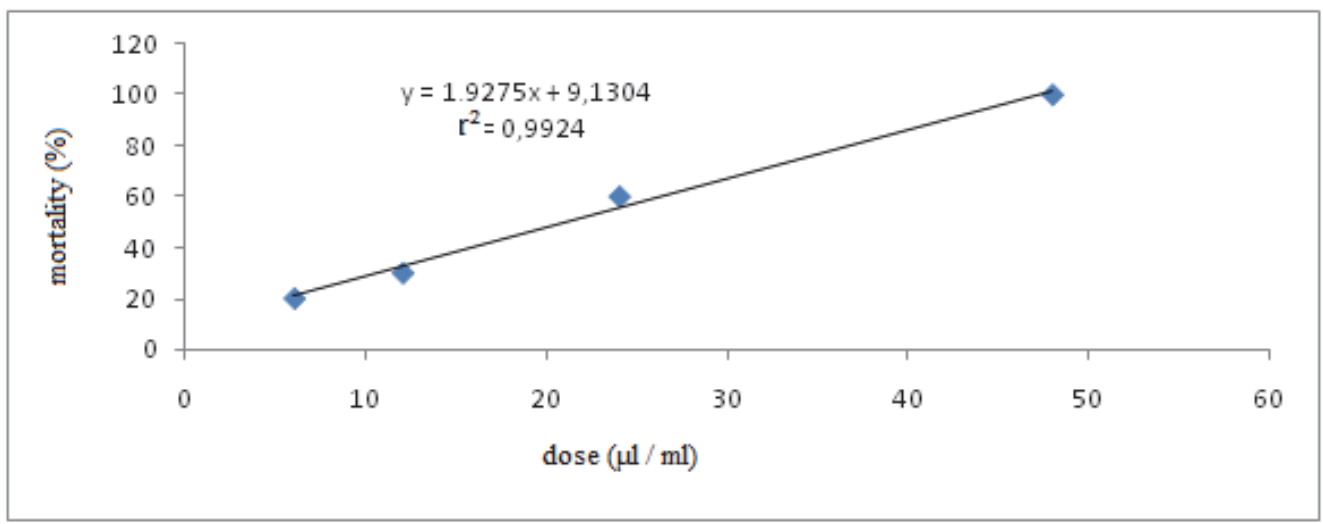

Figure 6. Linear regression line of mortality rates as a function of contact doses on C. barbarus for Eos

For its part, the ANOVA test (Table 3) showed that there was a significant difference between the doses and mortality $(\mathrm{P}=0.041<0.05)$. As a result, the mortality is higher the higher the dose.

The equation $(y=4.1827 \mathrm{x}+0.3548)$ is shown in Figure7.This latter permit us to obtained a LD50 dose of 12.58 $\mu \mathrm{l} / \mathrm{ml}($ Table 4$)$.

Table 3. Analysis of variance for EOs acting by contact

\begin{tabular}{llllllll}
\hline $\begin{array}{l}\text { Source } \\
\text { variations }\end{array}$ & $\begin{array}{l}\text { of } \\
\text { squares }\end{array}$ & $\begin{array}{c}\text { of } \begin{array}{l}\text { Degree } \\
\text { freedom }\end{array} \\
\text { Lignes }\end{array} 4^{\text {of }} \begin{array}{l}\text { Mean } \\
\text { squares }\end{array}$ & of $\mathrm{F}$ & Probability & $\begin{array}{l}\text { Critical value } \\
\text { for } F\end{array}$ \\
Colonnes & 1800 & 3 & 1 & 1483,33333 & 9,67391304 & 0,04728943 & 9,27662815 \\
Erreur & 460 & 3 & 1800 & 11,7391304 & $\mathbf{0 , 0 4 1 6 5 2 3 1}$ & 10,1279645 \\
Total & 6710 & 7 & 153,333333 & & & \\
\hline
\end{tabular}




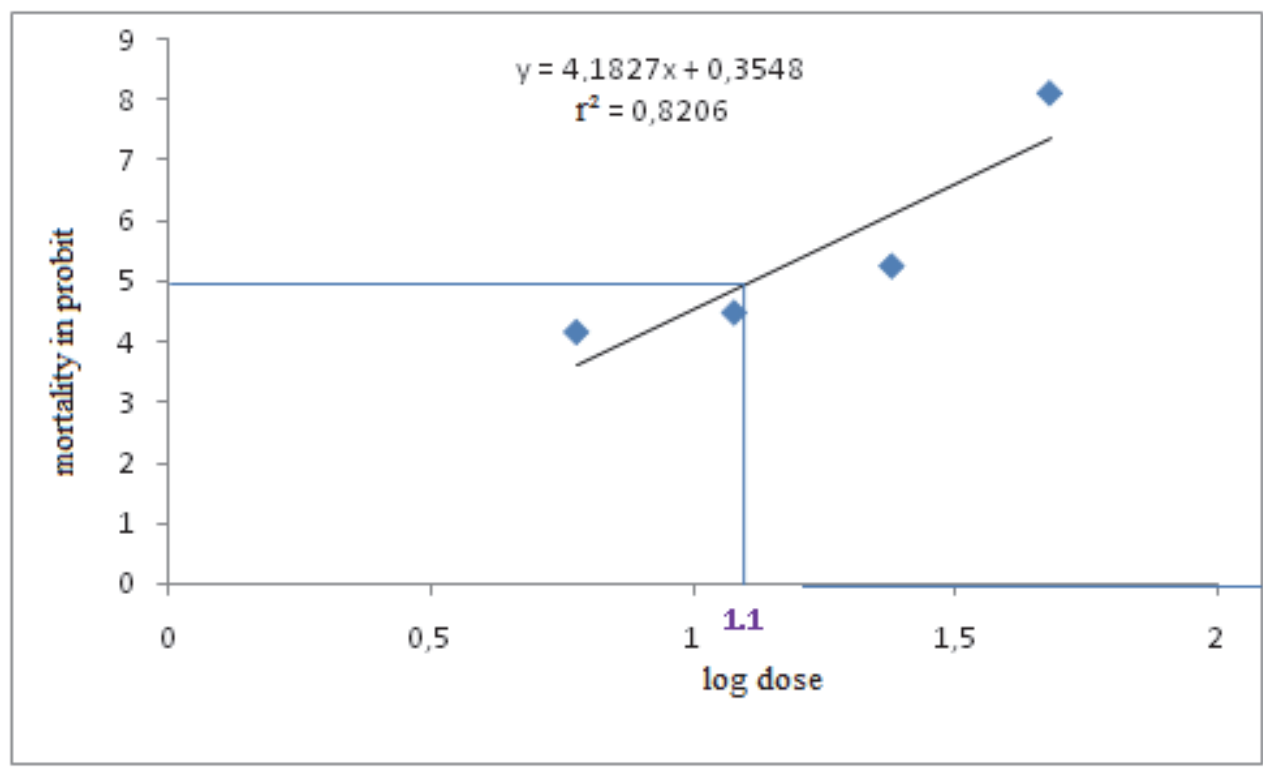

Figure 7. Determination of LD 50 for the test of Eos

Table 4. Log dose and LD 50 dose

\begin{tabular}{ll}
\hline Log dose & $\operatorname{Dose}(\mu \mathrm{l} / \mathrm{ml})$ \\
\hline 1,1 & 12,58 \\
1,38 & 23,98 \\
\hline
\end{tabular}

\subsubsection{Effect by Ingestion}

Figure 8 showed that whatever the doses used, the mode of action by ingestion gave no results on the first two days. It produced a rate between 10 and $20 \%$ after four day of treatment. Then, mortality changed significantly on day 6 , from $10 \%$ for the lowest dose $(6 \mu \mathrm{l} / \mathrm{ml})$ to $80 \%$ for the highest dose $(48 \mu \mathrm{l} / \mathrm{ml}$, Figure 8$)$.

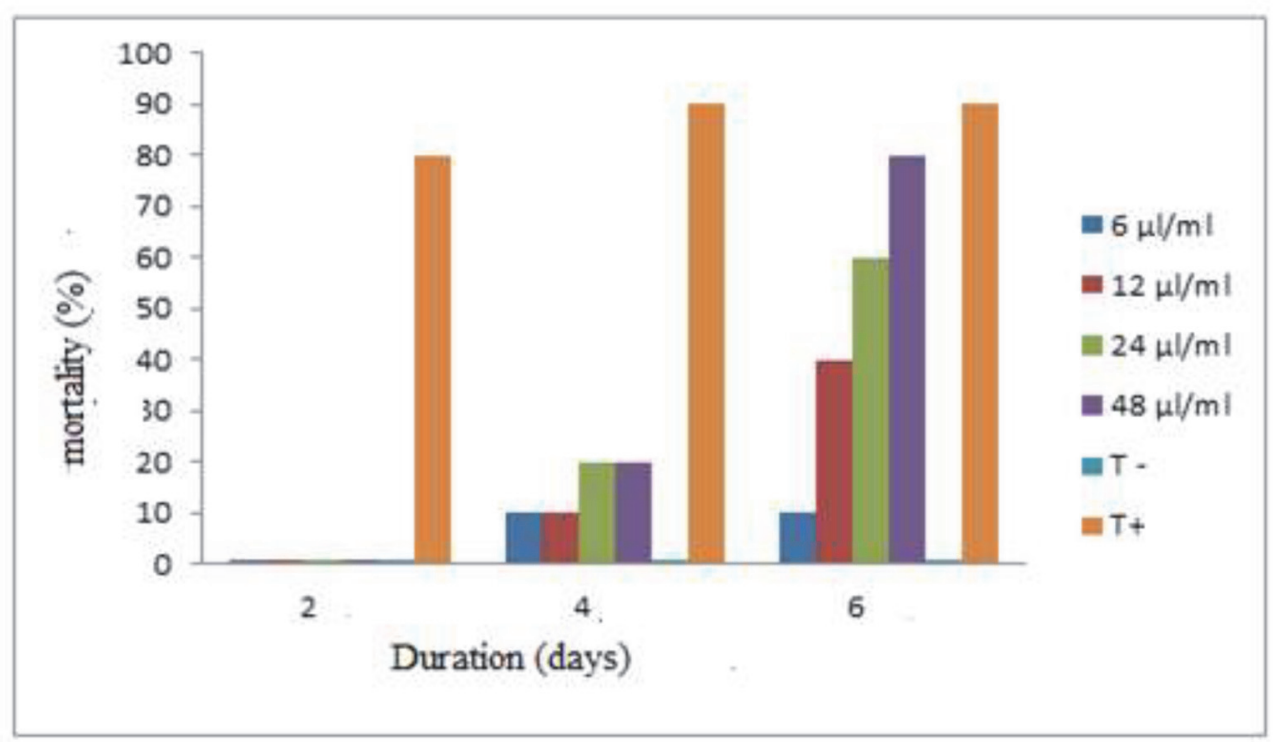

Figure 8. Ingestion Effect of EOs 
For the alimentation test, the equation of the linear regression line is: $y=1.4928 \mathrm{x}+13.913$ with a correlation coefficient $r^{2}=0.8622$ (Figure9). therefore $86,22 \%$ of the variation in mortality in the larval population of $C$. barbarus is due to the effect by ingestion of treatment with essential oils of Pennyroyal On the other hand, the ANOVA test revealed a probability $\mathrm{P}=0.04<0.05$ (Table5). There is therefore a significant difference between the two factors. In consequence, the higher the dose, the greater the mortality rate. By the same way, to calculate the LD 50, doses are converted to log doses and cumulative mortality in Probit (Table 6). From the data of this table, the equation of the linear regression line equal toy $=2.2791 \mathrm{x}+2.0879$ is calculated (Figure 10 ). Thanks to table 4 we obtained a LD50of $24 \mu \mathrm{l} / \mathrm{ml}$.

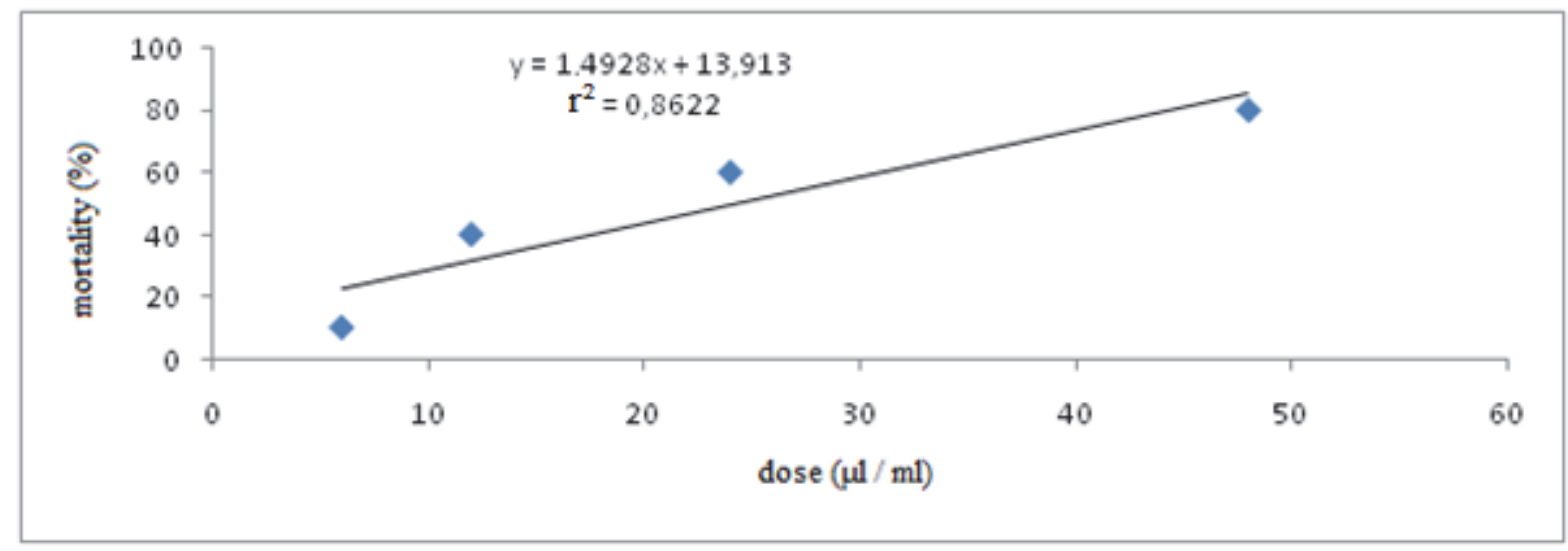

Figure 9. Linear regression line of mortality rates as a function of doses by ingestion on C. barbarus for Eos

Table 5. Analysis of variance for Eos acting by ingestion

\begin{tabular}{|c|c|c|c|c|c|c|c|c|}
\hline $\begin{array}{l}\text { Source des } \\
\text { variations }\end{array}$ & $\begin{array}{l}\text { Sum } \\
\text { squares }\end{array}$ & of & $\begin{array}{l}\text { Degree } \\
\text { freedom }\end{array}$ & of & $\begin{array}{l}\text { Mean of } \\
\text { squares }\end{array}$ & $\mathrm{F}$ & Probability & $\begin{array}{l}\text { Critical value } \\
\text { for } F\end{array}$ \\
\hline Lines & 3400 & & 3 & & 1133,33333 & 10,9677419 & 0,03996068 & 9,27662815 \\
\hline Columns & 1250 & & 1 & & 1250 & 12,0967742 & 0,04011205 & 10,1279645 \\
\hline Error & 310 & & 3 & & 103,333333 & & & \\
\hline Total & 4960 & & 7 & & & & & \\
\hline
\end{tabular}

Table 6. Logarithms of doses and Probit of cumulative mortality for the test by ingestion of EOs

\begin{tabular}{llll}
\hline Dose $(\mu 1 / \mathrm{ml})$ & Log dose & Cumulative mortality $(\%)$ & Probit \\
\hline 6 & 0,778 & 10 & 3,72 \\
12 & 1,079 & 40 & 4,75 \\
24 & 1,380 & 60 & 5,25 \\
48 & 1,681 & 80 & 5,84 \\
\hline
\end{tabular}




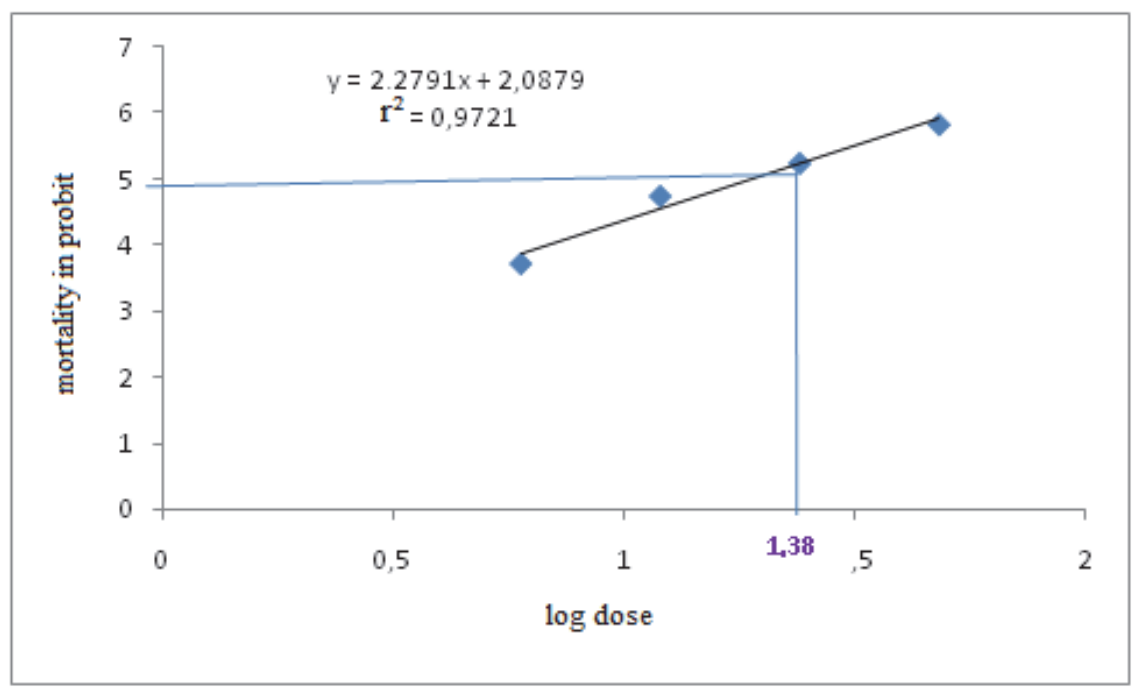

Figure 10. Determination of LD 50 for the test by ingestion of Eos

According to (Benayad, 2008), essential oils of M. pulegium proved very effective against two Coleoptera species: the rice thistle Sitophilus oryzae (Curculionidae) and the grain capuchin Rhyzopertha dominica (Bostrichidae). Insect mortality was total, as early as $24 \mathrm{~h}$ after treatment, but at low doses ( 3 and $12 \mu \mathrm{l} / \mathrm{ml}$, Benayad, 2008). The two experiments seem to be similar, except that to reach this $100 \%$, the concentration used for the present work is higher $(48 \mu \mathrm{l} / \mathrm{ml})$. In all cases, these studies show that the EOs of this plant have an excellent insecticidal power both on the Coleoptera and on the Orthoptera. Against Tribolium castaneum(Coleoptera: Tenebrionidae), Karahacene (2015) obtained a total mortality after $12 \mathrm{~h}$ of treatment of the dried leaves but using inhalation way at the dose of $20 \mu \mathrm{l} / \mathrm{ml}$ for a LD50 of $7.05 \mu \mathrm{l} / \mathrm{ml}$, therefore lower than that obtained by contact in our work (12.58 $\mu \mathrm{l} / \mathrm{ml}$ ).Essential oils of pennyroyal also have a larvicidal action against mosquitoes Anophelesaegypti (Diptera: Culicidae) where Rochaet al. (2015), registered 100\% mortality 48-h after treatment bycontact.

by comparing the results obtained with the positive test we can say that the EOs gave more satisfaction by contact ( $100 \%$ of mortality) from the 1 st day of treatment for the dose $(48 \mu \mathrm{l} / \mathrm{ml})$, whereas by ingestion, the insecticide has shown more satisfaction. In fact, from the start $(24 \mathrm{~h})$, it caused $80 \%$ mortality whereas to obtain this same rate with EOs, it was necessary to wait until the 6th day of treatment but having only used the highest dose $(48 \mu \mathrm{l} / \mathrm{ml})$

\subsubsection{Comparative Effect Between the Action by Contact and By Feeding}

Figure11showedthe results compared of the two modes of action. It should be noted that the effectiveness effect bycontact is stronger than by ingestion. This can be confirmed by the result obtained only after 3 days after treatment by contact (total mortality) greater than that obtained after 6 days by feeding $80 \%$ (Figure11).This difference in mortality time is interpreted among others by the difference between the faster mode of penetration by contact than by ingestion, the mode by ingestion being a physiological process requiring the intervention of enzymes thus asking the oils more time to be able to act. However, by looking at figure 11 we notice that the 2 curves cross at the level of the $3 \mathrm{rd}$ dose, this means that used at $24 \mu \mathrm{l} / \mathrm{ml}$, the EOs cause the same effect on the larvae of $C$. barbarus by contact or by ingestion (same mortality rate: $60 \%$ )

In contrast, Abdelliet al. (2016) believe that at low dose of EOs, the method by ingesting is more effective followed by inhalation method, while the process by contact is active only at higher doses.

According to Chiasson and Beloin (2007), this difference can be explained by the direct action of the oils on the cuticle of insects and other soft-body Arthropods. It remains, however, to determine the mechanism by which these EOs degrade the external cuticle of certain insects and mites. The lipophilic nature of the essential oil can degrade the waxy layer and cause water losses (Ketohet al., 1998). For them, as regards ingestion, most of the time, the action of bioactive substances in EOs is generally due to inhibition of growth regulators in the treated insect. 


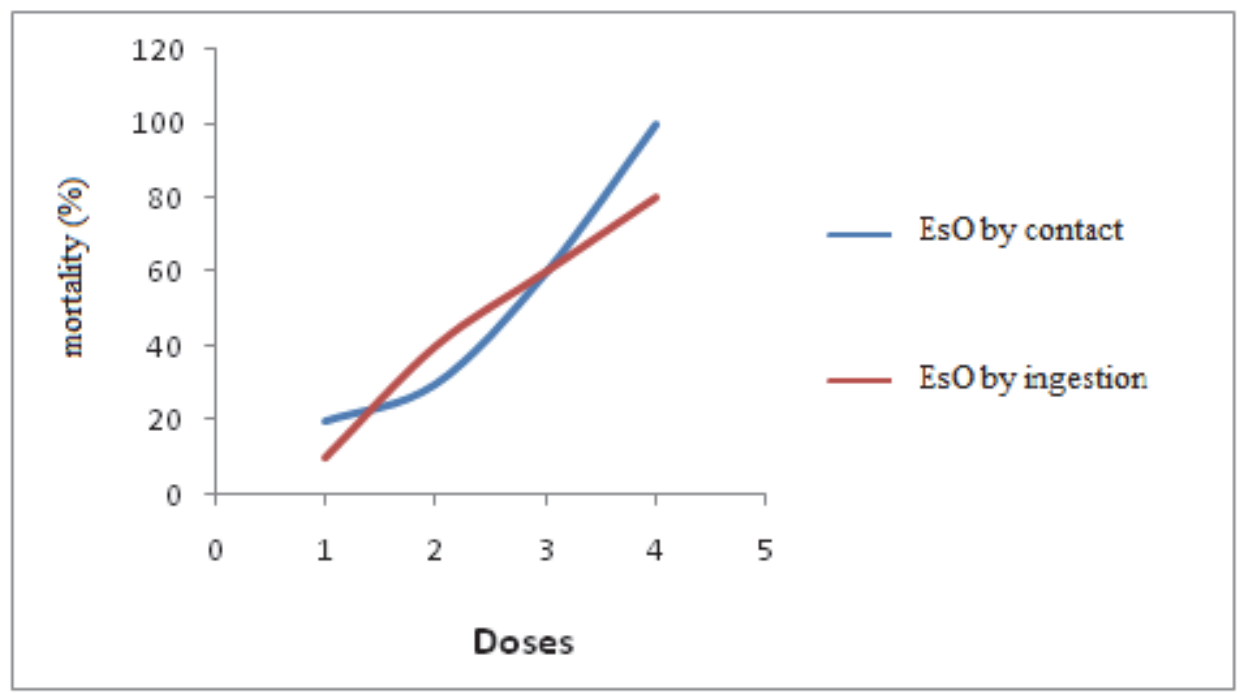

Figure 11. Comparison between acridicidal effect by ingestion and by contact

\section{Conclusion}

In order to combat C. barbarus a potential pest of crops, essential oils have been extracted from leaves of Pennyroyal: M. pulegium. These substances have been applied as bioacridicides by contact and by ingestion against juveniles of this insect. The results recorded after the biological tests were very satisfactory. After treatment of the larvae, the best efficacy was obtained using contact at the dose of $48 \mu \mathrm{l} / \mathrm{ml}$ (total mortality after 3 days of treatment). This has even exceeded that of the chemical insecticide (Aceplan), with which the mortality rate is $90 \%$.

It should be noted that the highest mortality rates are recorded with the highest doses either by ingestion ( 6 days) or by contact ( 3 days). Concerning lethal dose to kill $50 \%$ of population

It is to register a LD 50 of $12.58 \mu \mathrm{l} / \mathrm{ml}$ by contact and $23.98 \mu \mathrm{l} / \mathrm{ml}$ by ingestion.

It should also be noted that these results are obtained with only the active ingredients without any adjuvant. It will be interesting to know what their effect will be by adding substances such as stabilizers, surfactants or other antioxidants and synergists.

It would also be very interesting to study during a next work the effect of these same essential oils but this time on the adults of of $C$. barbarus to see if they will have the same effect as on the larvae of this species

Finally we can conclude that the results obtained are very convincing given the performances obtained, it is true that at low doses the results are less satisfactory compared to the conventional use of the insecticide (Aceplan 20) in particular by oral route but compared to this the last of which the negative impact on health and the environment is no longer to demonstrate the use of essential oils as a biopesticide leaving no trace of residues is now becoming a necessity.

\section{References}

Abbassi, K., Mergaoui, L., Atay-Kadiri, Z., Gaout, S., \& Stambouli, A., (2005). Activités biologiques des feuilles de Peganum harmala (Zygophyllacea) en floraison sur la mortalité et l'activité génésique chez le Criquet pèlerin. Faculté des Sciences, Université de Rabat, 16, 31-46.

Abdelli, M., Moghrani, H., Aboun, A., \& Maachi, R., (20016). Algerian Mentha pulegium L. leaves essential oil: Chemical composition, antimicrobial, insecticidal and antioxidant activities. Industrial Crops and Products, 94, 197-205. http://dx.doi.org/10.1016\%2Fj.indcrop.2016.08.042

Alloum, K. (2007). Les plantes médicinales d'Algérie.Edition Berti, 240p.

Beloued, A. (2009). Plantes médicinales. In plantes médicinales d'Algérie. Office des Publications Universitaires (OPU). $5^{\text {ème }}$ édition, Alger,139p.

Benayad, N. (2008). Les huiles essentielles extraites des plantes médicinales marocaines: moyen efficace de lutte 
contre les ravageurs des denrées alimentaires stockées. Rapport d'étude. Université Mohammed V-Agdal, $61 \mathrm{p}$.

Benzara, A. (2004). Polymorphisme géographique de l'espèce Calliptamus barbarus (Costa, 1836) (Orthoptera: Acrididae) en Algérie. Thèse Doctorat. Ins Nat. Agro., El Harrach, Alger, 154p.

Benzara, A., Ben Abdelkrim, A., \& Khalfi-Habes, O. (2013). Effect of extracts of seeds of aqueux Peganum harmala L. (zygophyllaceae) on 5th stage larvae Locusta migratoria cinerascens(Fabricius, 1781) (Orthoptera: Oedipodinae). Journal of life science, 7(2), 154-163.

Benzara, A., Khalfi-Habes, O., \& Lazib, Z., (2010). Efficacité des extraits aqueux de Peganumharmala (Zygophylacée) sur les larves L5 du Criquet pèlerin, Schistocerca gregaria (Forsskâl, 1775) (Orthoptera, Acrididae). Procedings du 7 ème Congrès de l'Association Marocaine de Protection des Plantes, Rabat. Pp: 469-474.

Bouziane, N. (2012). Toxicité comparée des extraits d'Euphorbia guyoniana Boiss et Reut (Euphorbiaceae) et de Peganum hamala L.(Zygophylaceae) récoltées au Sahara septentrionale de l'est Algérien sur les larves et les adultes de Scistocerca gregaria Forskal, 1775). Thèse de Magister, Université de Ouargla. 72p.

Casiglia, S. Bruno, M., Fontana G., \& Senatore, F., (2017). Chemical Composition of the Essential Oil of Mentha Pulegium Growing Wild in Sicily and its Activity on Microorganisms Affecting Historical Art Crafts. Natural Product Communications, 12(8), https://doi.org/10.1177\%2F1934578X1701200840

Chalchat, J. C., Gorunovic, M. S. Maksimović, Z. A., \& Petrovic, S. D. (2000). Essential Oil of Wild Growing Mentha pulegium L. from Yugoslavia. Journal of Essential Oil Research, 12, 598-600. https://doi.org/10.1080/10412905.2000.9712166

Chiasson, H., \& Beloin, N. (2007). Les huiles essentielles, des biopesticides « nouveau genre ». Bulletin de la Société d'entomologie du Québec, 14(1), 3-6.

Clemente, M. E., Garcia, M. D., \& Presa, J. J. (1987). Morphometric and pigmentary variation in Calliptamus barbarus (Costa, 1836) in relationship with environnement, and its taxonomic value, in Evolutionary Biology of Orthopteriod insects. Ed. Boccetti, Ellis Homood Ltd, Chichester, 184-189.

El Haib, A. (2011). Valorisation de terpenes naturels issus de plantes marocaines par transformations atalytiques. Thèse Doct. Université de Toulouse, $181 \mathrm{p}$.

Idrissi Hassani, L. M., \& El Hadek, M. (1999). Analyse de la composition de l'huile de Peganum harmala L. (Zygophyllacées). Acta botanica Gallica: Bulletin de la Société botanique de France, 146(4), 353-359. https://doi.org/10.1080/12538078.1999.10515822

Idrissi Hassani, L. M., \& Herms, J. (2008). Effets de l'alimentation en Peganum harmala L (Zygophyllaceae) sur le tube digestif du Criquet pélerin Schistocerca gregaria Forsk. (Orthoptera, Acrididae). Université Ibn Zohr, Agadir, 19, 71-84.

Idrissi Hassani, L. M., Ould Ahmedou, M. A., Chihrane, J., \& Bouaichi, A. (1998). Effets d'une alimentation en Peganum harmala (Zygophyllaceae) sur la survie et le développement ovarien du criquet pèlerin Schistocerca gregaria Forskål (Orthoptera, Acrididae), Ethnopharmacologia, 23, 26-41.

Idrissi Hassani, L. M., Ould Ahmedou, M. L., Mayad, E. H., \& Bouaichi, A. (2002). Pouvoir insecticide de Peganum harmala sur Schistocerca gregaria: effets de l'huile et des extraits de feuilles. Biologie \& santé, 2(2), 122-133.

Iserin, P. (2001). En cyclopedia des plantes médicinales. Edition Larouse, Paris, 335p.

Isman, M. B. (2000) Plant essential oils for pest and disease management. Crop Protection, 19, 603-608. https://doi.org/10.1016/S0261-2194(00)00079-X

Karahacene, T. (2015). Activité insecticide de quelques plantes cultivées et spontanées sur les insectes du blé en post récolte. Thèse doctorat, Ecole Nationale Supérieure d'Agronomie, Alger, 166.

Karousou, R., Balta, M., Hanlidou, E., \& Kokkin, S. (2007). Mints”, smells and traditional uses in Thessaloniki (Greece) and other Mediterranean countries. J Ethnopharmacol, 109(2), 248-57. https://doi.org/10.1016/j. jep.2006.07.022 PMID:16962274.

Ketoh, K., Glitho, A., Nuto, Y., \& Koumaglo, K. (1998). Effets de six huiles essentielles sur les oeufs et les larves de Callosobruchus maculatus F. (Coleoptera: Bruchidae). Revue cames. Volume W 00: 16-20. 
Lahlou, M. (2004). Methods to study phytochemistry and bioactivity of essential oils. Phytotherapy Research, 18, 435-448. https://doi.org/10.1002/ptr.1465

Larrosa, E., Ggarcia, M. D., \& Clemente, M. E., Presa, J. J. (2004). El comportamiento en cautividad de Calliptamus barbarus (Orthoptera:Acrididae). Memorie della Societa entomologica italiana, 82(2), 615-630.

Marzouk, B., Ben Hadj Fredj, M., Chraief, I., Mastouri, M., Boukef K., \& Marzouk, Z. (2008). Chemical composition and antimicrobial activity of essential oils from Tunisian Mentha pulegium L. Journal of Food, Agriculture \& Environment, 6(1), 78-82. http:/www.world-food.net/

Mbiantcha, M., Kamanyi, A., Teponno, R. B., Tapondjou, A. L., Watcho, P., \& Nguelefack, T. B. (2011). Analgesic and Anti-Inflammatory Properties of Extracts from the Bulbils of Dioscorea bulbifera L. var sativa (Dioscoreaceae) in Mice and Rats.Evidence-Based Complementary and Alternative. Médicine. 2011, Article ID 912935, 9. http:///dx.doi.org/10.1155/2011/912935

Moghrania, A., Abounb, H., \& Maachi, R., (2016). Algerian Mentha pulegium L. leaves essential oil: Chemical composition, antimicrobial, insecticidal and antioxidant activities. Industrial Crops and Products, 94, 197205.

Pavida, D. L., Lampman, G. M., \& Kriz, G. S. (1976). Introduction to organic laboratory techniques. Ed. W.B. Sauders Co. Philadelphia, 567 p.

Pino, J. A., Rosado, A., \& Fuentes, V. (1996). Chemical Composition of the Essential Oil of Mentha pulegium L. from Cuba. Journal of Essential Oil Research, 8(3), 295 296. https://doi.org/10.1080/10412905.1996.9701043.

Regnault-Roger, C., philogène, B. J. R., \& Charles, V. (2008). Biopesticides d'origine végétale. Editions Tec \& Doc-Lavoisier, 546p.

Regnault-Roger, C., Vincent, C., \& Philogene, B. J. R. (2002). Produits phytosanitaires, insecticides d'origine végétale: promesses d'hier et d'aujourd'hui. In: Biopesticides d'origine végétale. Ed.TEC et DOC- Lavoisier, Paris. 1013 p.

Rocha, D., Novo, M.T., Matos, O., \& Figueiredo, A. C. (2015). Potential of Mentha pulegium for mosquito control. Revista de Ciências Agrárias, 38(2), 155-165.

Rouibah, M. (2019). Insecticidal Potency of Aqueous Extracts of Seeds and Leaves of Harmal Peganum Harmala (Zygophyllaceae) on Juveniles of Calliptamus barbarus (Orthoptera: Calliptaminae): Contact and Ingestion Effects. Int J Zoo Animal Biol (2019), 2(11). https://doi.org/10.23880/izab-16000196

Rouibah, M., López-López, A., Presa, J., \& Doumandji, S. (2016). A molecular phylogenetic and phylogeographic study of two forms of Calliptamus barbarus. (Costa 1836) (Orthoptera: Acrididae, Calliptaminae) from two regions of Algeria Annales de laSociété entomologique de France, 52(2), 77-87. https://doi.org/10.1080/00379271.2016.1188329

Rouibah, M., Hamouda, A., \& Badache, N. (2019). Geometric morphometrics study of wing shapes in the Calliptamus barbarus (Orthoptera: Acrididae). Advances in Agricultural Science, 7(2), 22-32.

Stoyanova, A., Georgie, E., Kula, J., \& Majda, T. (2005). Chemical composition of the essential oil of Mentha pulegium from Bulgaria. Journal of Essential Oil Research, 17, 475-476. https://doi.org/10.1080/10412905.2005.9698968

Tahri, N., Rhalem, N., \& Soulaymani, R. (2004). L'intoxication au Harmal, Peganum harmala. Esperance Med, $10(5)$.

Wichtl, M., \& Anton, R., (1991). Plantes thérapeutiques: tradition pratique, officinale sciences et thérapeutique. Kinesitherapi, 7, 63-65.

\section{Copyrights}

Copyright for this article is retained by the author(s), with first publication rights granted to the journal.

This is an open-access article distributed under the terms and conditions of the Creative Commons Attribution license (http://creativecommons.org/licenses/by/4.0/). 